\title{
OEDICHIRUS SPELAEUS N. SP., THE FIRST CAVE DWELLING BEETLE FROM MADAGASCAR (COLEOPTERA: STAPHYLINIDAE: PAEDERINAE)
}

\author{
Arnaud Faille ${ }^{1,2, C}$ and Jean-Claude Lecoq ${ }^{3}$
}

\section{Abstract}

During an expedition of the French National Museum of Natural History in the Tsingy de Namoroka National Park, we systematically collected the cave fauna. Various mainly troglophilic species were found, but one of the most surprising discoveries was a Staphylinidae belonging to a new species and remarkable for its morphologic adaptations: reduced eyes, long antennae and legs, and depigmentation. This species is the first cavernicolous beetle described from Madagascar. A description of the new species is provided, as well as molecular data and details of the ecology of the species.

\section{Introduction}

In spite of a high level of endemism of biodiversity in Madagascar, the cave fauna of this island is surprisingly poor. In particular, beetles, which are the most diversified group of insects in hypogean environments, are virtually lacking. The only species previously known from Madagascan caves are not considered as true troglobites (Rémillet, 1973). A single species of Scarabaeidae, Cambefortantus myops (Lebis), was considered as potentially troglobitic, but its microphthalmy is not a troglomorphic character, as it is also observed in epigean species of the same genus (Montreuil 2008).

Two other beetle species are known from Madagascan caves, a water beetle of the family Elmidae, Elmidolia binervosa lamarcquei Paulian, 1959, which is considered troglophilic but does not show any troglomorphic characters (Rémillet 1973), and a Staphylinidae Pselaphinae, Centrophthalmus troglophilus Jeannel, 1954 (= Camaldus Fairmaire, Jeannel, 1954). Although nothing is said regarding the collection of the latter species in Andranoboka Cave, Jeannel (1954) indicated that the species is winged and has eyes.

The genus Oedichirus belongs to the subfamily Paederinae, tribe Pinophilini (Schomann and Solodovnikov, 2017). Paederinae is the subfamily of Staphylinidae sensu stricto (i.e., excluding Pselaphinae) the most common in subterranean ecosystems (25 species quoted in Hlavàč et al., 2006), but only a single species of Pinophilini was described from a cave in the Galapagos islands (Campbell and Peck, 1989). The genus Oedichirus is characterized morphologically by the spiniform pencil of antennomere 11, the abdominal segments IV to VI having windows in the intersegmental membrane adjacent to the tergum and sternum, an abdomen with a strongly punctate surface, tergum and sternum VII fused except for an apical incision, and elytra without a long seta on the lateroapical angle (Herman, 2010, 2013). It is speciose and widespread, with 330 species described from all continents except for Antarctica (Herman, 2013; Assing, 2013, 2014; Irmler, 2015; Li et al., 2015). The genus Oedichirus has undergone a major evolutionary radiation in Madagascar, with 107 species described so far (Lecoq, 1986, 1991; Janák, 1995, 1996, 1998, 2003). Little is known regarding the ecology of these species, which were mainly collected by beating vegetation or sifting leaf litter (Janák, 2003; Assing, 2014; Li et al, 2015).

The tsingys of Madagascar are remarkable and distinctive geological formations, jagged, sharp-edged pinnacles whose dissolution led to the creation of a complex underground cave network (Salomon, 2006, Raharimahefa, 2012, Veress et al, 2008). The Tsingy de Namoroka is one of the four tsingy areas of Madagascar, together with Bemaraha, Ankarana, and Bemarivo (Rossi, 1977; Fig. 1); it is located in the Boeny region of the northwestern part of the island. It is composed of about $180 \mathrm{~km}^{2}$ of needle-shaped Jurassic limestone formations, under a dry tropical climate (Middleton, 2004) (Fig. 2). Access to the tsingy is difficult, and it cannot be reached by car during the five months of the rainy season. As a result, its biodiversity - and especially the underground biocoenosis—is poorly known. The cave network has been explored by speleologists during various expeditions, but only limited data have been published regarding biological results and the cave fauna (Paulian and Grjebine, 1953; Rémillet, 1973; Soulier-Perkins et al, 2015).

\section{Materials and Methods}

Sampling: Specimens were collected by hand in the field and killed in ethyl acetate for morphological studies or 95\% ethanol for DNA extraction.

Morphological Preparation: After dissection or DNA extraction, specimens were mounted on cards and the genitalia glued behind the specimen or stored in water-soluble dimethylhydantoin formaldehyde resin (DMHF) on transparent

${ }^{1}$ Institute of Evolutionary Biology (CSIC-Universitat Pompeu Fabra), Barcelona, Spain

${ }^{2}$ MECADEV - UMR 7179 MNHN/CNRS, Paris, France

${ }^{3} 4$ rue du centre, Angaïs, France

${ }^{\mathrm{C} C o r r e s p o n d i n g ~ a u t h o r: ~ a r n a u d 1140 @ y a h o o . f r ~}$ 


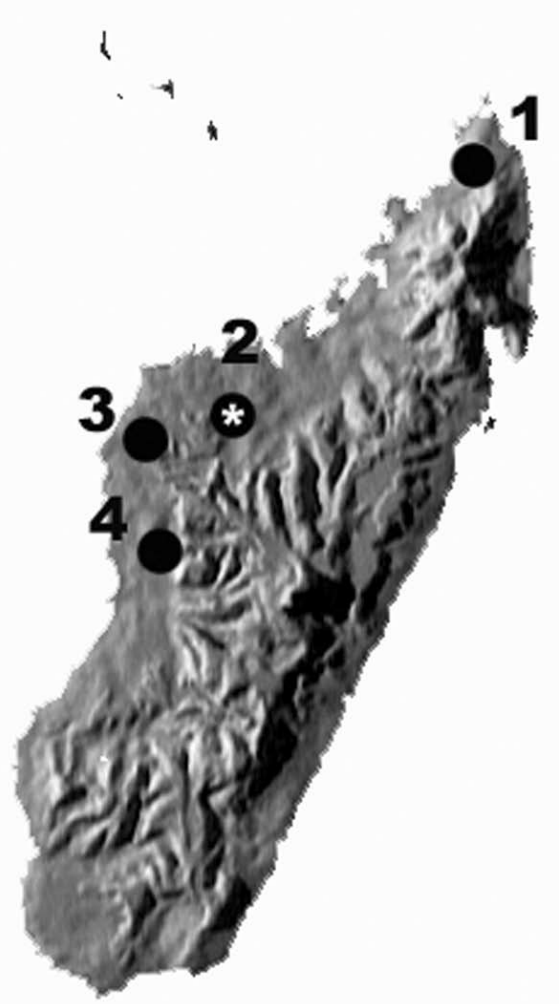

Figure 1. Location of the four main Tsingys areas in Madagascar. 1. Ankarana, 2. Namoroka, 3. Bemarivo, 4. Bemaraha. Asterisk: location of Oedichirus spelaeus n. sp.

cards pinned beneath the specimen. Pictures were taken with a Canon EOS 6D camera combined with a Cognisys Rail macro Stack Shot driven by the software Helicon Remote. Serial pictures were combined using the Helicon Focus 6 software, and finally processed using Adobe Photoshop CS.

Molecular Preparation: Non-destructive DNA extractions of single specimens were carried out using the DNeasy Tissue Kit (Qiagen $\mathrm{GmbH}$, Hilden, Germany). A partial fragment of the cox1 gene was PCR-amplified and sequenced. The primers used were Pat and Jerry, a couple frequently used in beetles (Simon et al, 1994).

Repository: Muséum national d'Histoire naturelle (MNHN), Paris.

\section{Results}

\section{Description}

Oedichirus spelaeus n. sp. (Figs. 3-5)

Type Material: Holotype ${ }^{\prime}$ : Madagascar Namoroka 29.X.2016 / Grotte du Canyon S16²4.676' E045¹9.645' alt. 161 m, A. Faille leg., extraction code: ZSM_L1464 (MNHN).

Paratypes: 1 ઈ, 2 \&, same data as holotype (MNHN); 1 ô, Namoroka 23.X.2016 / Grotte des Chauves-souris, S16 $24.501^{\prime} \mathrm{E} 045^{\circ} 18.662^{\prime}$ alt. $90 \mathrm{~m}$, A. Faille leg., extraction code: ZSM_L1461 (MNHN).

Etymology: the specific epithet is derived from the Greek omń $\lambda$ aı habitat of the new species.

Length: 8 to $10 \mathrm{~mm}$ (in extension). Forebody: $3.6 \mathrm{~mm}$ (from labrum to apex of elytra).

General appearance of body slender, with troglobiomorphic characteristics: legs slender, antennae long and slender, eyes strongly reduced. Apterous species, lateral border of pronotum complete. 
Coloration: body uniformly reddish-brown; legs, antennae, and maxillary palpi pale-yellowish.

Head: eyes strongly reduced, not prominent, $0.5 \times$ as long as temples. Head nearly square, slightly longer (from labrum to neck constriction) than wide $(R=1.14)$; temples subparallel, long, neck constriction well marked. Head much narrower than pronotum, strongly and densely punctate; punctation simple, strong and uniformly distributed. Distance between puncta greater than their diameter. Each punctum with fine lines radiating from its center. A small reticulate area at base of head. Some (ca. 50) long setae, uniformly distributed over surface of head. Antennae particularly long and thin, longer than the head and pronotum, measured from the labrum to the base of pronotum $(R=1.3)$ (length 3.5 $\mathrm{mm})$.

Maxillary palpi long, each of the three last segments longer than intermediary antennomere.

Pronotum: slightly longer than broad $(\mathrm{R}=1.14)$, much broader than the head $(\mathrm{R}=1.3)$, widest anteriorly in first third and tapering posteriorly; punctation strong and complex, each punctum surrounded by fine convergent lines. Sparsely pubescent; an irregular longitudinal sulcus on each side of the median line, each with ca. 15 punctae vaguely aligned. Lateral to the sulci, a succession of 5 or 6 weakly aligned punctae occurs in a shorter sulcus. Lateral border complete.

Elytra: short, as long as wide at apex, narrower than pronotum at the base and as wide as it at the apex. Humeral angles obsolete. Elytra progressively widening from base to apex. Surface covered with setiferous tubercles, the integument between the tubercles smooth, not reticulate.

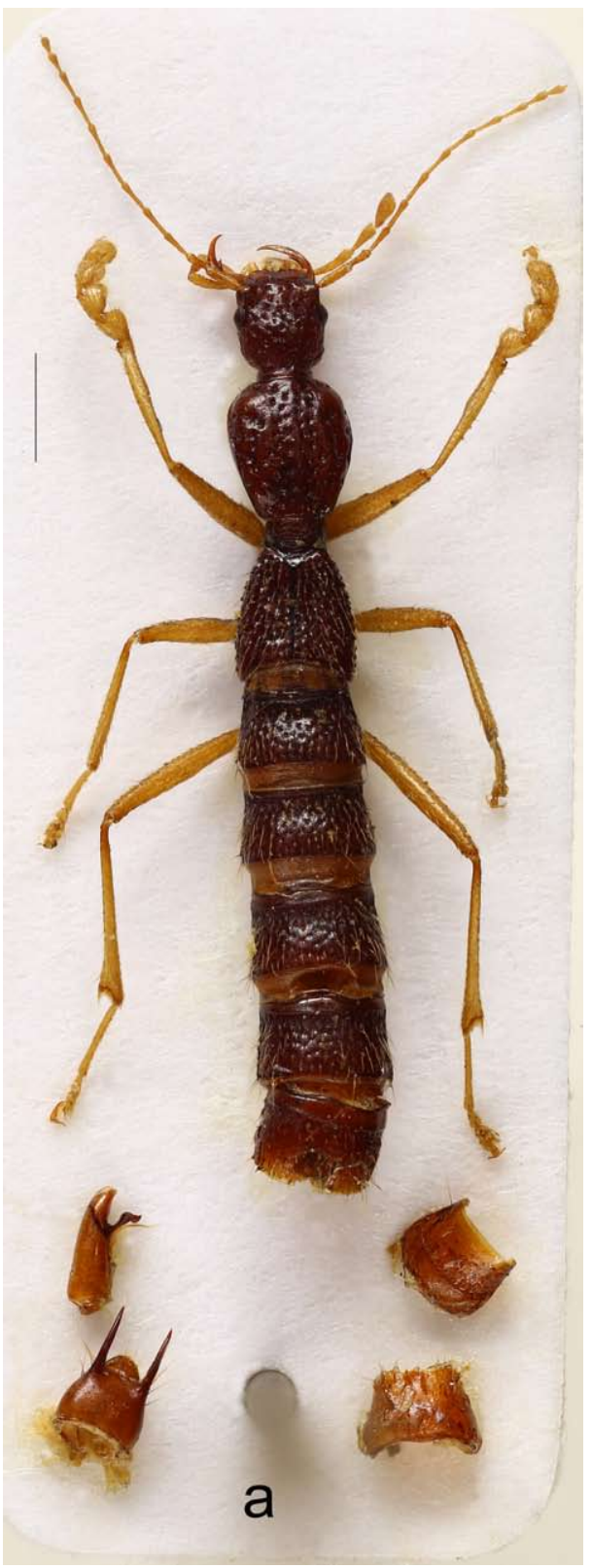
Lateral tubercles numerous. Setae long and thin. Hind wings absent. Scutellum wrinkled.

Abdomen: pubescent, with dense, uniform punctation. Abdominal segments wider than elytra, regularly covered with setigerous punctae slightly smaller than those of the forebody, regularly spaced, distance between adjacent punctae roughly equal to their diameter. Setae long and thin, similar to those on elytra. Integument nearly smooth, with some thin, fine lines around punctae. Tergite of genital segment (Tergum IX) with two long, parallel, sharp lateroapical processes (Fig. 4a, lower left). Sternite VIII of male with circular depression covered with short and recumbent setae, with some longer setae around this depression.

Aedeagus: asymmetrical, parameres slender, inserted near middle of median lobe, Lateral odd process enlarged in its median part (Fig. 5).

Diagnosis: O. spelaeus $\mathrm{n}$. sp. shares apterism and a complete lateral border in pronotum with the species of Oedichirus of the first section of Fagel (1970), but it can be readily separated by the presence of troglobiomorphic characteristics: legs and antennae long and slender, eyes strongly reduced.

Molecular data: The cox1 partial sequence of the holo-

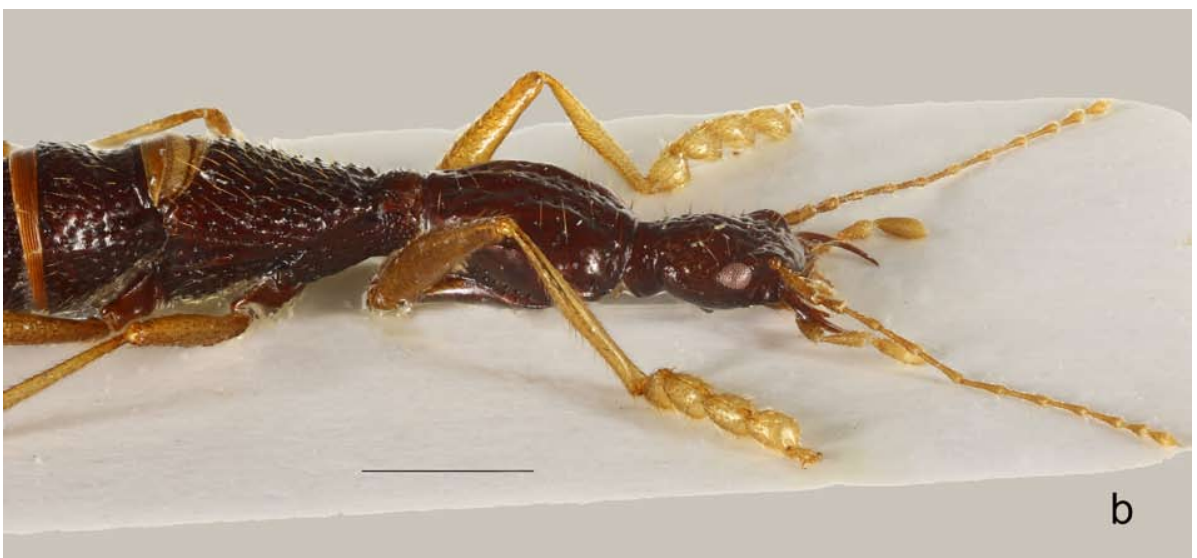

Figure 4.. Oedichirus spelaeus n. sp. habitus, in a. dorsal and b. lateral views. Scale $=1 \mathrm{~mm}$. 


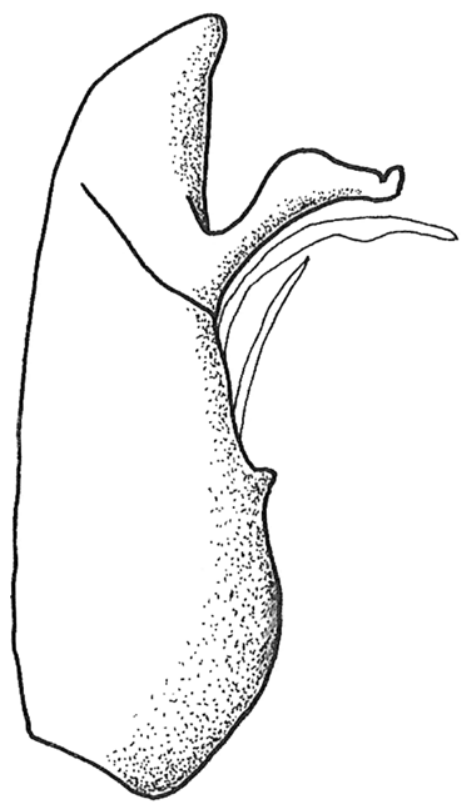

Figure. 5. Oedichirus spelaeus n. sp., holotype, median lobe in lateral view, scale $=1 \mathrm{~mm}$.

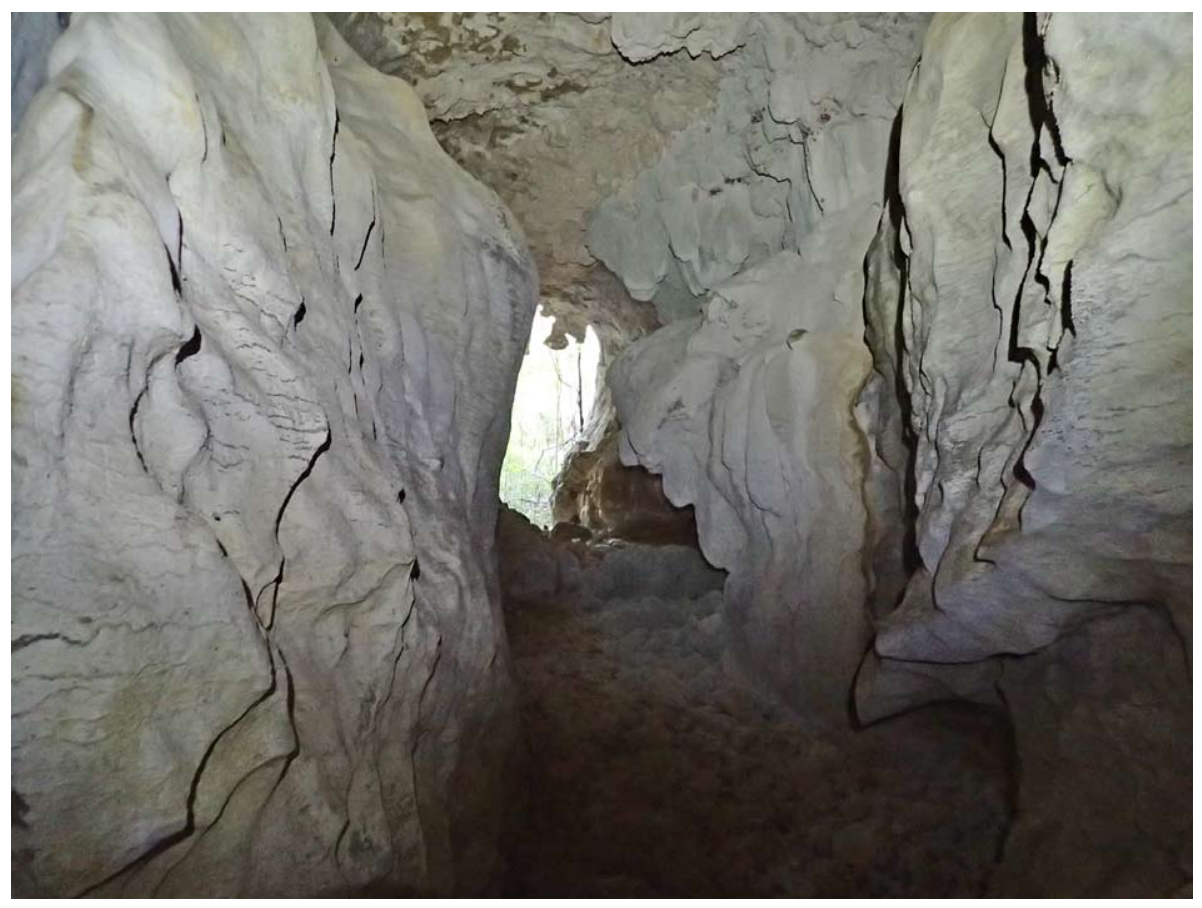

Figure 6. Namoroka, entrance to Grotte du Canyon (Canyon Cave).

type is deposited in GenBank under the accession number: MF795058. These are the first data for Oedichirus available in Genbank.

Distribution and ecology: This species is known from four specimens found in the deepest parts of two caves of the northern area of the Namoroka Tsingy: Grotte du Canyon (Canyon Cave, type locality, three exemplars) (Fig. 6) and Grotte des Chauves-souris (=Bat Cave, one exemplar) (Fig. 7a).

\section{Discussion}

The new species belongs to the first section comprising apterous species with a complete lateral border in pronotum (Fagel, 1970, Lecoq, 1986). It is difficult to relate the species unambiguously to any species of this group, in particular, because of the numerous characters reflecting the hypogean lifestyle of $O$. spelaeus.

Oedichirus spelaeus n. sp. was collected in two caves located in the northern part of the Tsingy de Namoroka National Park, ca. $35 \mathrm{~km}$ southeast of Soalala. Like the other Madagascan tsingys, Namoroka hosts a remarkable biodiversity (Allorge and Haevermans, 2015). The new species was discovered during the 2016 expedition organized by MNHN in Namoroka, which concentrated on the exploration of the northern part of the tsingy. The Grotte des Chauvessouris (=Bat Cave) is a long cave, an important part of which is formed by a canyon, ending in a large chamber with various lateral galleries and small chambers, these generally being dry in the season of the expedition (Fig. 7a, b). The network is developed on two levels, the new species having been found in the second, lower level (Fig. 7b) in company with a rich fauna of invertebrates, including Araneae, Amblypygi, Diplopoda, Polydesmida, Chilopoda, Isopoda, Zygentoma Nicoletiidae, Blattodea Nocticolidae (blind), Hemiptera Reduviidae Emesinae, Homoptera Cixiidae Typhlobrixia namorokensis Synave, 1953, Coleoptera Carabidae Abacetus (Astigis) sp., Collembola. Canyon Cave, the second locality where the new species was collected, is located in a remote area of the massif, on the side of a deep canyon crossing the tsingy (Fig. 6). It is a large cave with various underground passages, ending by a narrow joint. This is the deepest part of this cave, and it is here that Oedichirus spelaeus $\mathrm{n}$. $\mathrm{sp}$. was collected, walking on the ground, together with various troglobites, including Opiliones, Araneae, Hemiptera Reduviidae, the Cixiidae Typhlobrixia namorokensis, Blattodea Nocticolidae, and a new species of Staphylinidae Scaphidiinae (Löbl and Faille 2017).

\section{Acknowledgements}

We thank the Malagasy authorities, the staff of MNP (Madagascar National Parks), Marc Gansuana and the staff of EWE Madagascar and the residents of the Namoroka area for their invaluable help during the expedition. Thanks also to Sylvain Gilson for providing drone picture of the tsingy and Gernot Kunz for the picture of the species in nature. We are grateful to Thierry Deuve, Antoine Mantilleri, and Azadeh Taghavian for allowing us to compare the new species with the rich collection of Malagasy Oedichirus in the MNHN, and Mark Judson (MNHN) for language editing. Financial 

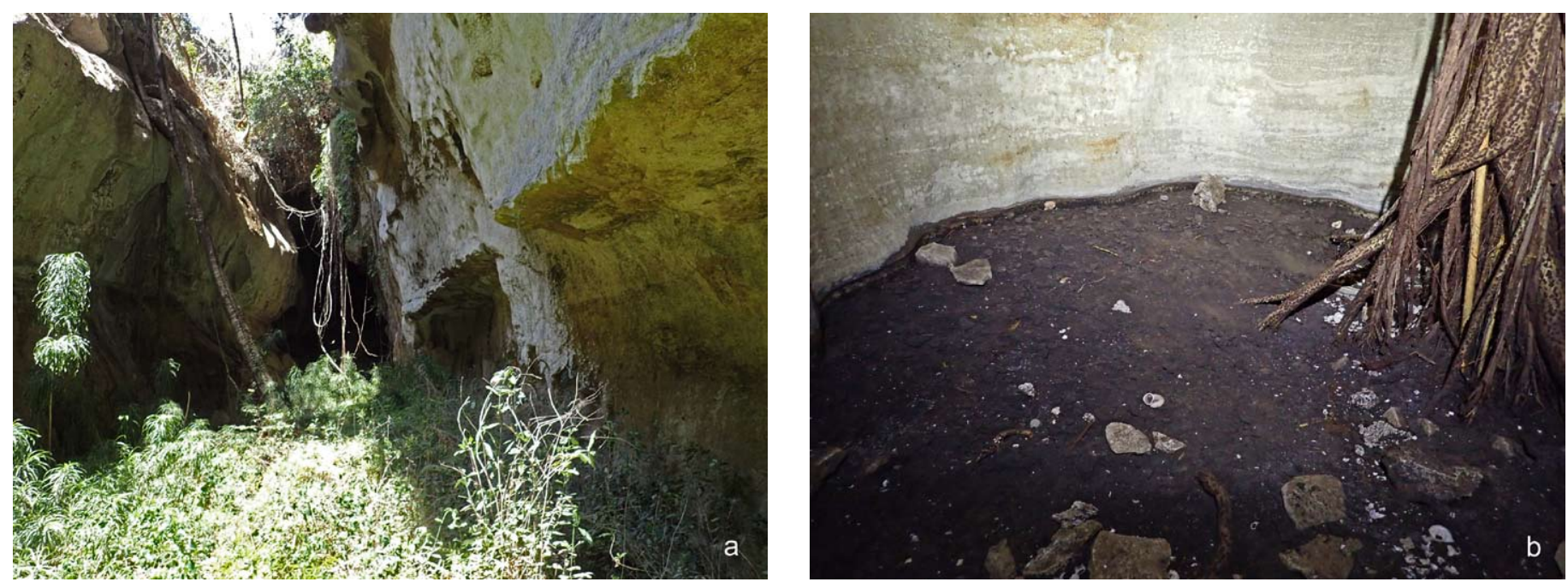

Figure 7. Namoroka, Grotte des Chauve-souris (=Bat Cave), a. entrance, b. chamber in which the new species was collected.

support for the Namoroka 2016 expedition was provided by Chanel Parfums Beauté. The photo shown in Figure 3 was provided by G. Kunz and the photo shown in Figure 2 was provided by S. Gilson.

\section{References}

Allorge, L., and Haevermans, T., eds., 2015, Namoroka, Mission à Madagascar: Paris, Muséum national d'Histoire naturelle and Éditions Privat, $160 \mathrm{p}$.

Assing, V., 2013, Three new species of Paederinae from Northeast India (Coleoptera: Staphylinidae): Linzer Biologische Beiträge, v. 45, no. 2, p. $1561-1570$.

Assing, V., 2014, On the Oedichirus fauna of China (Coleoptera: Staphylinidae: Paederinae): Linzer Biologische Beiträge, v. 46, no. 2, p. 1229-1240.

Campbell, J.M., and Peck, S.B., 1989, Pinostygus galapagoensis, new genus and species of eyeless rove beetle (Coleoptera: Staphylinidae: Paederinae) from a cave in the Galapagos Islands, Ecuador: The Coleopterists Bulletin, v. 43, p. 397-405.

Fagel, G., 1970, Révision des genres Procirrus Latreille, Palaminus Erichson, Oedichirus Erichson et voisins de la faune africaine (Coleoptera, Staphylinidae, Paederinae): Annales du Musée Royal d'Afrique Centrale, Tervuren, v. 186, p. 444 p.

Herman, L., 2010, Generic revision of the Procirrina (Coleoptera: Staphylinidae: Paederinae: Pinophilini): Bulletin of the American Museum of Natural History, v. 347, 78 p.

Herman, L., 2013, Revision of the New World Species of Oedichirus (Coleoptera: Staphylinidae: Paederinae: Pinophilini: Procirrina): Bulletin of the American Museum of Natural History, no. 375, 137 p.

Hlaváč, P., Oromí, P., and Bordoni, A., 2006, Catalogue of troglobitic Staphylinidae (Pselaphinae excluded) of the world: Subterranean Biology, v. 4, p. $19-28$.

Irmler, U., 2015, New species and new records of the Neotropical genera Gnathymenus Solier, 1849 and Oedichirus Erichson, 1839 (Coleoptera: Staphylinidae: Paederinae): Koleopterologische Rundschau, v. 85, p. 113-119.

Janák, J., 1995, Neue Arten und neue Funde der Gattung Oedichirus aus Madagaskar I. (Coleoptera, Staphylinidae, Paederinae, Pinophilini): Acta Coleopterologica, v. 11, no. 3, p. 15-21.

Janák, J., 1996, Neue Arten und neue Funde der Gattung Oedichirus aus Madagaskar II. (Coleoptera, Staphylinidae, Paederinae, Pinophilini): Acta Coleopterologica, v. 12, no. 3, p. 3-24.

Janák, J., 1998, Neue Arten und neue Funde der Gattung Oedichirus aus Madagaskar III. (Coleoptera: Staphylinidae: Paederinae: Pinophilini): Klapalekiana, v. 34, no.1-2, p. 45-60.

Janák, J., 2003, Neue Arten und neue Funde der Gattung Oedichirus aus Madagaskar IV. (Coleoptera: Staphylinidae: Paederinae: Pinophilini) Klapalekiana, v. 39, no. 4, p. 229-255.

Jeannel, R., 1954 (1953), Les Psélaphides de Madagascar: Mémoires de l'Institut Scientifique de Madagascar (E: Entomologie), v. 4, p. 139_ 344.

Lecoq, J.C., 1986, Faune de Madagascar 67. Insectes Coléoptères Staphylinidae Paederinae, I Pinophilini: Paris, Muséum national d’Histoire naturelle, $183 \mathrm{p}$.

Lecoq, J.C., 1991, Sur quelques Pinophilini de Madagascar: nouvelles espèces, nouvelles captures (Col. Staphylinidae Paederinae): Bulletin de la Société Entomologique de France, v. 95, no. 7-8, p.229-236.

Li, Wen-Rong, Xie, Nan-Nan, and Li, Li-Zhen, 2015, Redescription of Oedichirus flammeus Koch, and description of two new Oedichirus species from China (Coleoptera, Staphylinidae,Paederinae, Pinophilini): Zootaxa, v. 3911, no. 1, p. 81-90. https://doi.org/10.11646/zootaxa.3911.1.4

Löbl, I., and Faille, A., 2017, Toxidium cavicola sp. nov., a new cave dwelling Malagasy Scaphidiinae (Coleoptera: Staphylinidae): Annales Zoologici, v.67, no. 2, p. 345-348.https://doi.org/10.3161/00034541ANZ2017.67.2.011.

Middleton, G., 2004, Madagascar, in Gunn, J., ed., Encyclopedia of Caves and Karst Science, London, Fitzroy Dearborn (Taylor and Francis Group), p. 1085-1100.

Montreuil, O., 2008, Révision du genre Cambefortantus Paulian, 1986 (Insecta, Coleoptera, Scarabaeidae): Zoosystema, v. 30, no 3, p. $641-650$.

Paulian, R., and Grjebine, A., 1953, Une campagne spéléologique dans la réserve naturelle de Namoroka: Le Naturaliste Malgache, v. 5, no. 1, p. 19-26.

Raharimahefa, T., 2012, Geoconservation and geodiversity for sustainable development in Madagascar: Madagascar Conservation \& Development, v. 7, no. 3, p. 126-134.http://dx.doi.org/10.4314/mcd.v7i3.5. 
Rémillet, M., 1973 (1971), Aperçu de la faune souterraine à Madagascar: Livre du cinquantenaire de l'Institut de Spéléologie Emile Racovitza, Colloque National de Spéléologie, Bucarest (RO), 1971/11/02-11, Bucarest, Editura Academiei Republicii Socialiste România, p. 135-160.

Rossi, G., 1977, Karst tropical et structure, l'exemple malgache: Norois, v. 95b, p. 173-196.

Salomon, J. N., 2006, Les tsingy et leur genèse: Spelunca, v. 103, p.45-50.

Schomann, A.M., and Solodovnikov, A., 2017, Phylogenetic placement of the austral rove beetle genus Hyperomma triggers changes in classification of Paederinae (Coleoptera: Staphylinidae): Zoologica Scripta, v. 46, no. 3, p. 336-347. http://dx.doi.org/10.1111/zsc.12209.

Simon, C., Frati, F., Beckenbach, A., Crespi, B., Liu, Hong, and Flook, P., 1994, Evolution, weighting, and phylogenetic utility of mitochondrial gene-sequences and a compilation of conserved polymerase chain-reaction primers: Annals of the Entomological Society of America, v. 87, p. 651-701. https://doi.org/10.1093/aesa/87.6.651.

Soulier-Perkins, A., Ouvrard, D., Hoch, H., and Bourgoin, T., 2015, Singing in the Namoroka Caves, first record in situ for a cave dwelling insect: Typhlobrixia namorokensis (Hemiptera, Fulgoromorpha, Cixiidae): Journal of Insect Behavior, v. 28, no. 6, p.704-721. https://doi.org/10.1007/ s10905-015-9531-3.

Veress, M., Lóczy, D., Zentai, Z., Tóth, G., and Schläffer, R., 2008, The origin of the Bemaraha tsingy (Madagascar): International Journal of Speleology, v. 37, no. 2, p. 131-142. http://dx.doi.org/10.5038/1827-806X.37.2.6. 